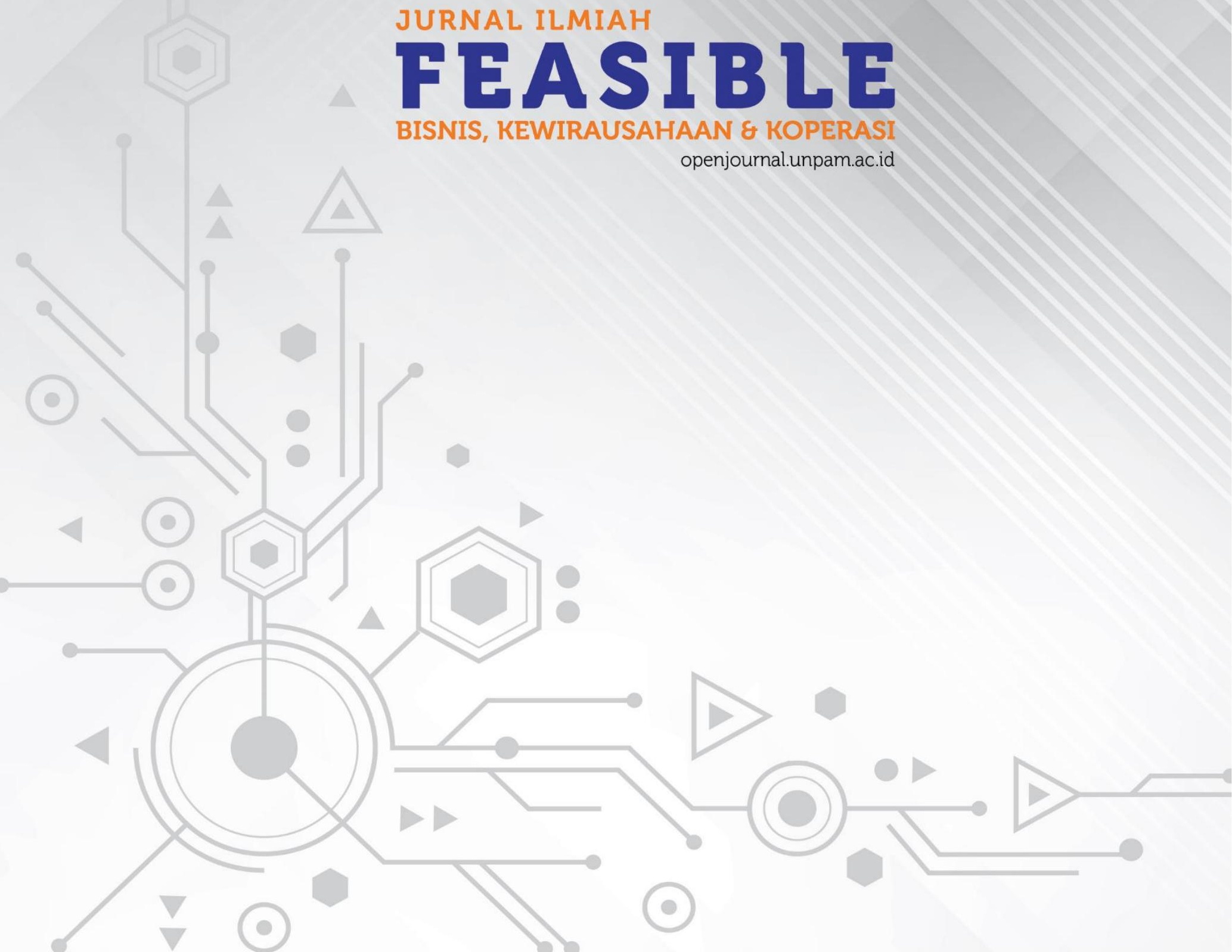


P-ISSN : 2655-9811, E-ISSN:2656-1964

J. Feasible., Vol. 2, No.2, Agustus $2020(217-228)$

0 2019 PusatinkubasiBisnis dan Kew irausahaan

Universitas Pamulang (PINBIKUNPAM)

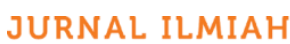

FEASIBLE

\title{
PENGARUH KUALITAS PELAYANAN DAN FASILITAS TERHADAP KEPUASAN BELAJAR SISWA SMK YADIKA 5 PONDOK AREN
}

\author{
Novia Susanti' ${ }^{\text {. Susi Ayuna Dewi² }}$ \\ Prodi Manajemen - Universitas Pamulang \\ doseno0768@unpam.ac.id
}

\begin{abstract}
Abstrak
Tujuan penelitian ini untuk mengetahui pengaruh kualitas pelayanan dan fasilitas terhadap kepuasan belajar siswa SMK YADIKA 5 Pondok Aren. Populasi dalam penelitian ini berjumlah 572 siswa sedangkan sampel yang diambil sebanyak 85 siswa menggunakan rumus slovin. Metode penelitian yang digunakan asosiatif kuantitatif dengan pengumpulan data observasi, kuesioner dan studi kepustakaan. Metode analisa data menggunakan analisis deskiptif, uji validitas, uji reabilitas, uji normalitas, uji multikolinieritas, uji heterokedastisitas, uji regresi linier sederhana, uji resresi linier berganda, uji koefisien korelasi, uji koefisien determinasi, uji uji-t dan uji $F$ (simultan). Hasil penelitian diperoleh bahwa secara parsial dan simultan kualitas pelayanan dan fasilitas berpengaruh signifikan terhadap kepuasan belajar siswa SMK Yadika 5 Pondok Aren.Di dukung dengan persamaan $Y=5.677+0.32 X_{1}+0.48 X_{2}$ dan nilai $F_{\text {hitung }} 34.557>F_{\text {tabel }}$ 2.36. Sedangkan besarnya konstribusi kualitas layanan dan faslitas terhadap kepuasan belajar sebesar sebesar $46.6 \%$.
\end{abstract}

Kata Kunci: Kualitas Pelayanan; Fasilitas; Kepuasan siswa

\begin{abstract}
The purpose of this study was to determine the effect of service quality and facilities on student satisfaction at SMK YADIKA 5 Pondok Aren. The population in this study amounted to 572 students while the sample taken was 85 students using the Slovin formula. The research method used is quantitative associative with observation data collection, questionnaires and literature study. The data analysis method uses descriptive analysis, validity test, reliability test, normality test, multicollinearity test, heteroscedasticity test, simple linear regression test, multiple linear regression test, correlation coefficient test, determination coefficient test, $t$-test and $F$ test (simultaneous). The results showed that partially and simultaneously the quality of services and facilities had a significant effect on student satisfaction at SMK Yadika 5 Pondok Aren. Supported by the equation $Y=5.677+0.32 X 1+0.48 X 2$ and the value of Fcount 34.557> Ftable 2.36. Meanwhile, the contribution of service quality and facilities to learning satisfaction was $46.6 \%$.
\end{abstract}

Keywords: Service Quality; Amenities; Student satisfaction 


\section{PENDAHULUAN}

\section{Latar Belakang}

Pendidikan adalah suatu yang penting atau ujung tombak kemajuan suatu bangsa karena dengan adanya pendidikan yang berkualitas akan menghasilkan sumber daya manusia yang berkualitas. Selain itu dunia pendidikan juga berfungsi untuk memberikan jasa pelayanan pendidikan yang bertujuan menghasilkan sumber daya yang berkualitas yang dan mampu menjadi penggerak pembangunan negara serta berfungsi untuk menghasilkan tenaga kerja yang berkualitas dari berbagai tingkat keahlian.

Pada saat ini kebutuhan masyarakat akan pendidikan semakin meningkat masyarakat menyadari akan pentingnya ilmu pendidikan untuk menghadapi tantangan dimasa depan dengan cara memiliki pendidikan yang berkualitas tinggi dengan adanya kualitas pendidikan yang tinggi masyarakat akan mampu mengembangkan diri untuk lebih maju dengan adanya kesadaran akan ilmu pendidikan yang tinggi membuat kebutuhan dalam masyarakat terhadap pendidikan serta juga ikut meningkat yang menyebabkan dibutuhkannya sekolah yang memiliki jasa layanan pendidikan yang berkualitas sehingga keberadaan sekolah ditengah masyarakat menjadi sangat penting melihat tingkat persaingan yang unggul sekolah menengah kejuruan di kota tangerang selatan baik yang dipimpin oleh pemerintah maupun swasta menjadi semakin kompetitif hal ini yang mendorong setiap sekolah untuk menetapkan srategi agar mampu merebut perhatian siswa dan menjadi sekolah unggulan. Salah satu sekolah menengah kejuruan (SMK) yang melakukan persaingan secara kompetitif dengan sekolah-sekolah lain adalah SMK YADIKA 5 Pondok Aren.

SMK YADIKA 5 Pondok Aren merupakan sekolah umum berstandar Nasional dengan standar pengembangan pendidikan abad 21, yang mendukung sarana pembelajarannya berbasis ICT (Information Computer Tecnology). Akselerasi progam pendamping pembelajaran milenialis yang mengakomodir pembelajaran berbasis HOTS (High Order Thingking Skill). SMK YADIKA 5 Pondok Aren memiliki VISI terwujudnya SMK berstandar nasional yang menghasilkan, tamatan berbudi pekerti, trampil memasuki dunia kerja dan mampu, berwirausaha, serta MISI mananamkan, keimanan dan budi pekerti, warga sekolah, melaksanakan kurikulum pembelajaran yang sesuai dengan kebutuhan dan perkembangan IPTEK baik pembejaran dikelas maupun praktik industri, meningkatkan professionalisme guru dan pihak manjemen sekolah, meningkatkan kualitas dan kuantitas sarana pendidikan, menanamkan keteramp,ilan dan motivasi berwirausaha. 
Beikut ini merupakan data jumlah siswa yang terdaftar di SMK YADIKA 5 Pondok Aren

\begin{tabular}{|c|c|c|c|}
\hline \multicolumn{4}{|c|}{ Tabel 1.1. Jumlah Siswa Terdaftar } \\
\hline Tahun Ajaran & $\begin{array}{l}\text { Target } \\
\text { Siswa }\end{array}$ & Jumlah Siswa & Presentase \\
\hline $2014-2015$ & 1000 siswa & 538 siswa & $53,8 \%$ \\
\hline $2015-2016$ & 1000 siswa & 601 siswa & $60,1 \%$ \\
\hline 2016-2017 & 1000 siswa & 636 siswa & $63,6 \%$ \\
\hline $2017-2018$ & 1000 siswa & 623 siswa & $62,3 \%$ \\
\hline 2018-2019 & 1000 siswa & 572 siswa & $57,2 \%$ \\
\hline
\end{tabular}

Data sarana dan prasarana yang terdapat pada SMK YADIKA 5 Pondok Aren yang mengalami kerusakan.

\begin{tabular}{|c|c|c|c|c|c|}
\hline \multicolumn{6}{|c|}{ Tabel 1.2. Sarana Dan Prasarana } \\
\hline $\begin{array}{l}\text { Nama } \\
\text { Ruang }\end{array}$ & $\begin{array}{c}\text { Kondisi } \\
\text { Baik }\end{array}$ & $\begin{array}{l}\text { Kondisi } \\
\text { Rusak } \\
\text { Ringan }\end{array}$ & $\begin{array}{l}\text { Kondisi } \\
\text { Rusak } \\
\text { Sedang }\end{array}$ & $\begin{array}{c}\text { Kondisi } \\
\text { Rusak } \\
\text { Berat }\end{array}$ & Jumlah \\
\hline Ruang Kelas & 0 & 19 & 0 & 0 & 19 \\
\hline Labortorium & 0 & 2 & 0 & 0 & 2 \\
\hline Perpustakaan & 0 & 1 & 0 & 0 & 1 \\
\hline Sanitasi & 0 & 4 & 0 & 0 & 4 \\
\hline Total & & & & & 26 \\
\hline
\end{tabular}

Data keluhan para siswa 'SMK YADIKA 5 Pondok Aren.

\begin{tabular}{|c|c|}
\hline \multicolumn{2}{|c|}{ Tabel 1.3. Data Keluhan Para Siswa } \\
\hline Siswa & Perihal \\
\hline Siswa & $\begin{array}{l}\text { 1. Speker di ruang lap tidak menyala di lap } \\
\text { computer ada beberapa perlatan yang rusak } \\
\text { 2. Peralatan di ruang kelas beberapa rusak, tempat } \\
\text { sampah dan pintu ada yang rusak }\end{array}$ \\
\hline Siswi & $\begin{array}{l}\text { 1. Beberapa guru bersikap kurang ramah } \\
\text { 2. tidak sesuai bidangnya çontoh a guru olahraga jadi } \\
\text { guru bahasa jepang } \\
\text { 3. Informasi yang diberikan sering terlambat dan } \\
\text { tidak jelas }\end{array}$ \\
\hline
\end{tabular}

\section{Rumusan Masalah.}

Rumusan permasalahan dalam penelitian ini meliputi:

1. Seberapa besar pengaruh kualitas pelayanan terhadap kepuasan belajar siswa/siswi, SMK YADIKA 5 Pondok Aren.

2. Seberapa besar pengaruh fasilitas terhadap kepuasan belajar siswa/siswi SMK YADIKA 5 Pondok Aren.

3. Seberapa besar pengaruh kualitas pelayanan dan fasilitas terhadap kepuasan belajar siswa/siswi SMK YADIKA 5 Pondok Aren.

\section{Tujuan penelitian}

Penelitian ini bertujuan untuk:

1. Mengetahui seberapa besar pengaruh kualitas pelayanan terhadap kepuasan belajar siswa SMK YADIKA 5 Pondok Aren

2. Mengetahui seberapa besar pengaruh fasilitas terhadap kepuasan belajar siswa SMK YADIKA 5 Pondok Aren

3. Untuk mengetahui seberapa besar pengaruh kualitas pelayanan dan fasilitas terhadap kepuasan belajar siswa SMK YADIKA 5 Pondok Aren

\section{Manfaat Penelitian}

Manfaat dari penelitian ini adalah:

1. Mengembangkan kemampuan ilmiah dalam menyelesaikan permasalahan menggunakan metode ilmiah yang benar dan tepat. 
2. Memberikan konstribusi perusahaan terkait dalam pengambilan keputusan untuk meningkatkan strategi peningkatan kualitas pelayan dan fasilitas yang baik yang dapat meningkatkan kepuasan peserta didik/pelanggan.

3. Memberikan konstribusi dan referensi bagi penulis maupun peneliti dalam hal upaya meningkatkan kepuasan pelanggan.

\section{Kajian Literatur}

\section{Kualitas}

Menurut Kotler (2012:49), "Kualitas adalah keseluruhan ciri serta sifat dari suatu produk atau pelayanan yang berpengaruh pada kemampuannya untuk memuaskan kebutuhan.” Sedangkan Juran (2010:36) menyatakan "Kualitas adalah kesesuaian dengan tujuan atau manfaatnya”. Goeth dan Davis dalam Tjiptono (2012:51), juga menyatakan bahwa "Kualitas merupakan suatu kondisi dinamis yang berhubungan dengan produk, jasa, manusia, proses, dan lingkungan yang memenuhi atau melebihi harapanharapan atas suatu produk atau jasa tersebut. Berdasarkan ketiga pengertian tersebut dapat diuraikan bahwa kualitas merupakan suatu sifat suatu produk/jasa dalam kondisi yang dinamis dengan kesesuaian tujuan dan manfaat untuk dapat memenuhi atau melebihi dinyatakan atau tersirat.

\section{Kualitas Pelayanan}

Kualitas Pelayanan merupakan salah satu elemen yang menjadi pertimbangan bagi pelanggan dalam menilai kepuasan. Menurut Tjiptono dan Chandra (2011:172) menyatakan bahwa kualitas pelayanan berkaitan erat dengan keputusan pelanggan. Kualitas pelayanan memberikan dorongan khusus bagi para pelanggan untuk menjalin ikatan ralasi saling menguntungkan dalam jangka panjang dengan perusahaan. Ikatan emosional semacam ini memungkinkan perusahaan untuk memahami dengan seksama harapan dan kebutuhan spesifik pelanggan. Selanjutnya definisi kualitas pelayanan menurut Mauludin (2013:67) mengemukakan bahwa kualitas pelayanan adalah seberapa jauh perbedaan antara kenyataan dan harapan pelanggan atas langganan yang mereka terima atau peroleh. Dari pendapat tersebut dapat disimpulkan bahwa kualitas pelayanan adalah salah satu elemen yang menjadi pertimbangan bagi pelanggan untuk mengetahui seberapa jauh perbedaan antara kenyataan dan harapan pelanggan atas langganan yang mereka terima atau peroleh.

\section{Fasilitas}

Menurut Zakiah Daradjat (2012:230) fasilitas adalah segala sesuatu yang dapat mempermudah upaya dan memperlancar kerja dalam rangka mencapai suatu tujuan. Sedangkan menurut Suryo Subroto (2010:22) Fasilitas adalah segala sesuatu 
yang dapat mempermudah dan memperlancar pelaksanaan suatu usaha dapat berupa benda-benda maupun uang. Lebih luas lagi tentang pengertian Fasilitas (Suhaisimi Arikonto) berpendapat fasilitas dapat diartikan sebagai segala sesuatu yang dapat memudahkan, memperlancar pelaksanaan suatu usaha. Tjiptono dan Gregorius Chandra (2016:184) juga menyatakan bahwa "fasilitas merupakan bentuk fisik atau atmosfir yang dibentuk oleh eksterior dan interior yang disediakan perusahaan dalam membangun rasa aman dan nyaman pelanggan”.

\section{Kepuasan Konsumen}

Kepuasan Konsumen adalah tingkat perasaan konsumen setelah membandingkan antara apa yang diterima dan harapannya Umar (2015: 65). Seorang konsumen, jika merasa puas dengan nilai yang diberikan oleh produk atau jasa, sangat besar kemungkinannya menjadi pelanggan dalam waktu yang lama. Sedangkan menurut Philip Kotler dan Kevin Lane Keller (2014: 177) mengatakan bahwa Kepuasan Konsumen adalah perasaan senang atau kecewa seseorang yang muncul setelah membandingkan kinerja (hasil) jasa yang diperkirakan terhadap kinerja yang diharapkan. Kotler dan Keller yang dikutip oleh Bob Sabran (2012:177) juga menyatakan bahwa kepuasan konsumen adalah merupakan perasaan senang atau kecewa seseorang yang muncul setelah membandingkan antara kinerja atau hasil yang diharapkanya. Lalu menurut Fandy Tjiptono (2012:146) kepuasan pelanggan adalah perasaan senang atau kecewa seseorang yang muncul setelah membandingkan antara persepsi terhadap kinerja (hasil) suatu produk dengan harapanharapanya.

Berdasarkan definisi di atas dapat disimpulkan bahwa kepuasan konsumen merupakan hasil dari perbandingan kesesuaian antara harapan dan kinerja dengan hasil yang di terima baik produk maupun jasa yang ditawarkan. Pada dasarnya nilai yang diberikan oleh produk ataupun jasa memungkinkan pelanggan menggunakan produk ataupun jasa yang ditawarkan dalam waktu yang lama. Oleh karena itu perlu dilakukan penelitian untuk menentukan harapan pelanggan agar perusahaan bisa memenuhi harapan tersebut.

\section{Kerangka Berfikir.}

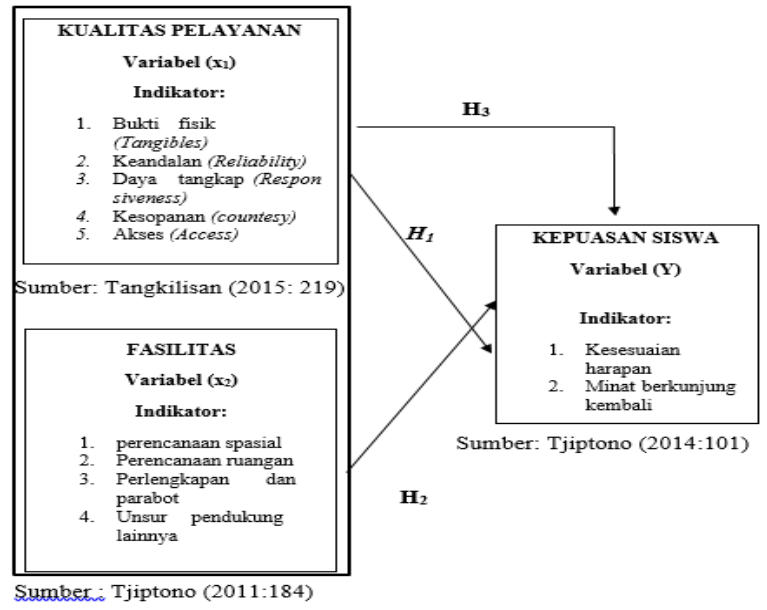

Gambar 1.1 Kerangka Berfikir 


\section{Hipotesis}

Dari kerangka berfikir dapat disusun hipotesis:

1. $\mathrm{H}_{\mathrm{o}}=\mathrm{o}$ : Diduga tidak terdapat pengaruh antara kualitas pelayanan terhadap kepuasan belajar siswa SMK YADIKA 5 Pondok Aren.

$\mathrm{H}_{\mathrm{a}} \neq \mathrm{O}$ : Diduga terdapat pengaruh antara kualitas pelayanan terhadap kepuasan belajar siswa SMK YADIKA 5 Pondok Aren.

2. $\mathrm{H}_{\mathrm{o}}=\mathrm{O}$ : Diduga tidak terdapat pengaruh antara fasilitas terhadap kepuasan belajar siswa SMK YADIKA 5 Pondok Aren.

$\mathrm{H}_{\mathrm{a}} \neq \mathrm{O}$ : Diduga terdapat pengaruh antara fasilitas terhadap kepuasan belajar siswa SMK YADIKA 5 Pondok Aren.

3. $\mathrm{H}_{\mathrm{o}}=\mathrm{o}$ : Diduga tidak terdapat pengaruh antara kualitas pelayanan dan fasilitas terhadap kepuasan belajar siswa SMK YADIKA 5 Pondok Aren.

$\mathrm{H}_{\mathrm{a}} \neq \mathrm{O}$ : Diduga terdapat pengaruh antara kualitas pelayanan dan fasilitas terhadap kepuasan belajar siswa SMK YADIKA 5 Pondok Aren.

\section{METODE}

Metode penelitian yang digunakan adalah bersifat deskriptif kuantitatif. Populasi dalam penelitian ini adalah seluruh peserta didik di SMK Yadika 5 Pondok Aren. Dengan menggunakan sampel jenuh menggunakan responden penelitian seluruh peserta didik yang berjumlah sebanyak 85 responden. Teknik data dengan cara kuesioner, dan teknik analisis data adalah uji validitas, uji reliabilitas, analisis regresi linear sederhana, analisis koefisien korelasi, koefisien determinasi, dan pengujian hipotesis.

\section{HASIL dan PEMBAHASAN}

\section{Hasil}

\section{Karakteritik Deskriptif Responden}

1. Berdasarkan Jenis Kelamin

Tabel 1.1. Karakteristik berdasarkan Jenis Kelamin

\begin{tabular}{|c|c|c|}
\hline Jenis kelamin & jumlah & presentase \\
\hline Laki-Laki & 30 & $35 \%$ \\
\hline Perempuan & 55 & $65 \%$ \\
\hline Jumlah & 85 & $100 \%$ \\
\hline
\end{tabular}

Sumber: Data primer yang diolah (2019)

Dari tabel jumlah responden laki-laki sebanyak 35\% dan perempuan sebanyak 65\% sehingga dapat disimpulkan bahwa siswa di SMK Yadika 5 Pondok Aren lebih banyak perempuan dibandingkan dengan laki-laki.

2. Berdasarkan Usia

Tabel 1.2. Karakteristik berdasarkan Usia

\begin{tabular}{|c|c|c|}
\hline Usia & jumlah & presentase \\
\hline <16 Tahun & 34 & $40 \%$ \\
\hline $16-20$ Tahun & 51 & $60 \%$ \\
\hline Jumlah & 85 & $100 \%$ \\
\hline \multicolumn{2}{|l}{ Sumber: Data primer yang diolah (2019) } \\
\hline
\end{tabular}


Dri tabel di atas, responden berusia kurang dari 16 tahun sebanyak 34\% dan berusia 16-20 tahun sebanyak 51\% sehingga dapat disimpulkan bahwa siswa di SMK Yadika 5 Pondok Aren mayoritas berusia 1620 tahun.

3. Berdasarkan Kelas

Tabel 1.3. Karakteristik berdasarkan
\begin{tabular}{|c|c|c|}
\hline Kelas \\
\hline Kelas & jumlah & presentase \\
\hline Sepuluh (X) & 26 & $31 \%$ \\
\hline Sebelas (XI) & 31 & $36 \%$ \\
\hline Dua Belas (XII) & 28 & $33 \%$ \\
\hline Jumlah & 85 & $100 \%$ \\
\hline
\end{tabular}

Sumber: Data primer yang diolah (2019)

\section{Uji Validitas Instrumen}

Uji validitas digunakan untuk mengukur sah atau tidaknya suatu kuestioner. Instrumen dikatakan valid jika nilai $r$ hitung (charonbatch Alpha) $\geq 0,30$ (Ghozali: 2013, h.52).

\section{Tabel 1.4. Hasil Uji Validitas Instrumen}

\begin{tabular}{|c|c|c|c|c|}
\hline variabel & pernyataan & Nilai r hitung & Nilair t tabel & keterangan \\
\hline \multirow{3}{*}{$\begin{array}{c}\text { Kualitas } \\
\text { pelayanan } \\
\left(X_{1}\right)\end{array}$} & Pernyataan1 & 0.620 & 0.30 & Valid \\
\cline { 2 - 5 } & Pernyataan2 & 0.547 & 0.30 & Valid \\
\cline { 2 - 5 } & Pernyataan3 & 0.691 & 0.30 & Valid \\
\cline { 2 - 5 } & Pernyataan4 & 0.704 & 0.30 & Valid \\
\cline { 2 - 5 } & Penyataan5 & 0.630 & 0.30 & Valid \\
\cline { 2 - 5 } & Pernyatann6 & 0.651 & 0.30 & Valid \\
\cline { 2 - 5 } & Pernyataan7 & 0.683 & 0.30 & Valid \\
\cline { 2 - 5 } & Pernyataan8 & 0.683 & 0.30 & Valid \\
\cline { 2 - 5 } & Pernyataan9 & 0.527 & 0.30 & Valid \\
\cline { 2 - 5 } & Pernyataan10 & 0.606 & 0.30 & Valid \\
\hline
\end{tabular}

\section{Uji Reliabilitas}

Uji reliabilitas digunakan untuk mengukur konsistensi dari suatu variabel. Butir pernyataan dalam variabel dikatakan reliable atau terpercaya apabila jawaban responden adalah konsisten atau stabil dari waktu ke waktu. Suatu konstruk atau variabel dikatakan reliable jika nilai Cronbach Alpha >0,60.

Tabel 1.5. Hasil Uji Reliabilitas Instrumen

\begin{tabular}{|c|c|c|c|}
\hline Variabel & Nilai Cronbach Alpha & Kriteria & Keputusan \\
\hline Kualitas pelayanan & 0.757 & $>0.60$ & Reliabel \\
\hline Fasilitas & 0.762 & $>0.60$ & Reliabel \\
\hline Kepuasan siswa & 0.771 & $>0.60$ & Reliabel \\
\hline
\end{tabular}

Sumber: Hasil Olahan Data SPSS 22 (2019)

Berdasarkan tabel di atas dapat di ketahui bahwa masing-masing variabel kualitas pelayanan, fasilitas dan kepuasan siswa memiliki nilai Cronbach Alpha > 0.60, sehingga keseluruhan variabel dinyatakan reliable.

\section{Deskripsi Jawaban Responden}

1. Hasil perhitungan jawaban responden berkaita dengan kualitas pelayanan SMK Yadika 5 Pondok Aren diperoleh rata-rata skor jawaban 3.89 pada interval 3.414.20. Sehingga kualitas pelayanan sekolah dikategorikan baik.

2. Hasil perhitungan jawaban responden berkaita dengan fasilitas SMK Yadika 5 Pondok Aren diperoleh rata-rata skor jawaban 3.84 pada interval 3.41-4.20. 
Sehingga fasilitas sekolah dikategorikan baik.

3. Hasil perhitungan jawaban responden berkaita dengan kepuasan siswa SMK Yadika 5 Pondok Aren diperoleh rata-rata skor jawaban 3.78 pada interval 3.414.20. Sehingga kepuasan siswa di sekolah dikategorikan baik.

\section{Uji regresi linier sederhana}

Menurut Sugiono (2014:270) "regresi sederhana didasarkan pada hubungan fungsional ataupun kausal satu variabel independen dengan satu variabel dependen".

\section{Tabel 1.6. Regresi linier Pengaruh Kualitas Pelayanan terhadap Kepuasan Coefficients $^{a}$}

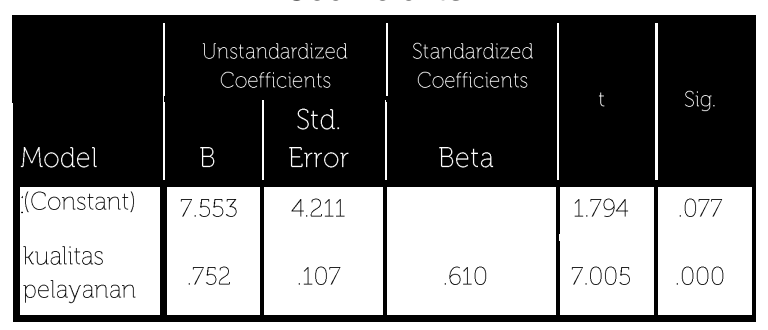

a. Dependent Variable: kepuasan siswa

Berdasarkan tabel di atas, persamaan regresi yang diperoleh $\mathrm{Y}=7.553+0.75 \mathrm{X}_{1}$, artinya nilai konstanta sebesar 7.553 mempunyai arti bahwa tanpa adanya kualitas pelayanan maka kepuasan siswa akan tetap bernilai 7.553. Sedangkan nilai koefisien regresi variabel kualitas pelayanan 0.75 bernilai positif mempunyai arti jika kualitas pelayanan meningkat maka akan dapat meningkatkan kepuasan siswa begitu pula sebaliknya. Dari hasil tersebut terbentuk model hasil penelitian yaitu berbanding lurus antara kualitas pelayanan terhadap kepuasan siswa, yaitu jika kualitas pelayanan baik maka kepuasan siswa naik koefisien regresi positif.

\section{Tabel 1.7. Regresi linier Pengaruh Fasilitas terhadap Kepuasan Coefficients $^{a}$}

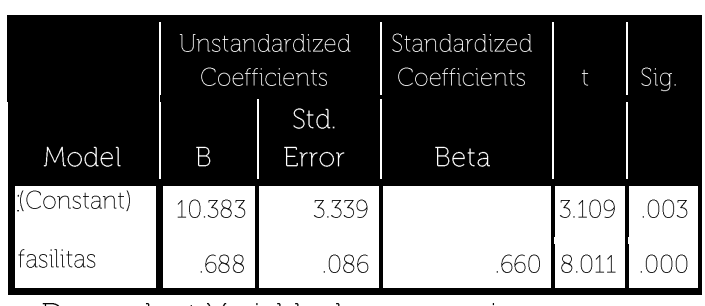

a. Dependent Variable: kepuasan siswa

Berdasarkan tabel di atas, diperoleh persamaan regresi $\mathrm{Y}=10.383+0.68 \mathrm{X}_{2}$, nilai konstanta sebesar 10.383 mempunyai arti bahwa tanpa adanya fasilitas maka kepuasan siswa akan tetap bernilai 10.383. Nilai koefisien regresi variabel kualitas pelayanan 0.68 bernilai positif mempunyai arti jika kualitas pelayanan meningkat maka akan dapat meningkatkan kepuasan siswa begitu pula sebaliknya. Dari hasil terbentuk model hasil penelitian yaitu berbanding lurus antara fasilitas terhadap kepuasan siswa, yaitu jika fasilitas baik maka kepuasan siswa naik.

\section{Uji regresi linier berganda}

Uji regresi linier berganda digunakan untuk mengetahui seberapa besar pengaruh variabel bebas (kualitas pelayanan dan fasilitas) terhadap variabel terikat (kepuasan).Hasil uji regresi berganda ditunjukkan tabel berikut: 


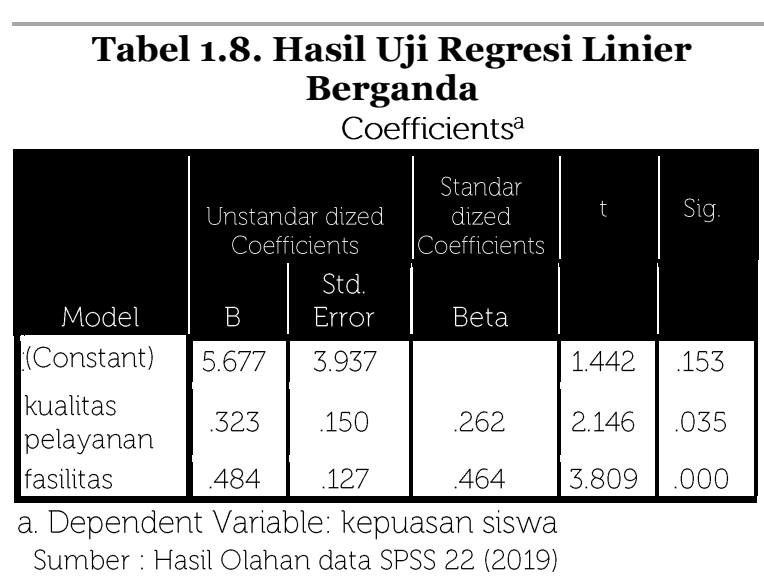

Berdasarkan tabel di atas, diperoleh persamaan regresi $\mathrm{Y}=5.677+0.32 \mathrm{X}_{1}+$ $0.48 \mathrm{X}_{2}$

1. Nilai konstanta sebesar 5.677 mempunyai arti bahwa tanpa adanya kualitas pelayanan dan fasilitas maka kepuasan siswa akan tetap bernilai 5.677.

2. Nilai koefisien regresi variabel kualitas pelayanan 0.32 bernilai positif mempunyai arti jika kualitas pelayanan meningkat maka akan dapat meningkatkan kepuasan siswa begitu pula sebaliknya.

3. Nilai koefisien regresi variabel fasilitas o.48 bernilai positif mempunyai arti jika kualitas pelayanan meningkat maka akan dapat meningkatkan kepuasan siswa begitu pula sebaliknya.

\section{Uji Koefisien Korelasi}

Analisis koefisien korelasi digunakan untuk mengengetahui hubungan antara variabel independen terhadap variabel dependen.

\section{Tabel 1.9. Hasil Uji Korelasi}

\begin{tabular}{|c|c|c|c|c|}
\hline & & \begin{tabular}{|l} 
kualitas \\
pelayanan
\end{tabular} & fasilitas & $\begin{array}{c}\text { kepuasan } \\
\text { siswa }\end{array}$ \\
\hline $\begin{array}{l}\text { kualitas } \\
\text { pelayanan }\end{array}$ & $\begin{array}{l}\text { Pearson } \\
\text { Correlation } \\
\text { Sig. (2-tailed) } \\
\text { N }\end{array}$ & 1 & $\begin{array}{l}.749^{* *} \\
.000 \\
85\end{array}$ & $\begin{array}{l}.610^{* *} \\
.000 \\
85\end{array}$ \\
\hline fasilitas & $\begin{array}{l}\text { Pearson } \\
\text { Correlation } \\
\text { Sig. (2-tailed) } \\
\mathrm{N} \\
\end{array}$ & $\begin{array}{l}.749^{* *} \\
.000 \\
85 \\
\end{array}$ & $\begin{array}{r}1 \\
85 \\
\end{array}$ & $\begin{array}{l}.660^{* *} \\
.000 \\
85 \\
\end{array}$ \\
\hline $\begin{array}{l}\text { kepuasan } \\
\text { siswa }\end{array}$ & $\begin{array}{l}\text { Pearson } \\
\text { Correlation } \\
\text { Sig. (2-tailed) } \\
\text { N }\end{array}$ & $\begin{array}{l}.610^{* *} \\
.000 \\
85\end{array}$ & $\begin{array}{l}.660^{* *} \\
.000 \\
85\end{array}$ & 85 \\
\hline
\end{tabular}

Berdasarkan tabel di atas dapat diketahui hubungan kualitas pelayanan terhadap kepuasan sebesar 0,61, fasilitas dengan kepuasan sebesar 6,60. Karena koefisien tersebut berada diantara o,6o - o,79 maka korelasi/hubungannya tergolong kuat. (Muhammad Idrus 2010, 168)

\section{Uji Koefisien Determinasi}

Uji koefisien determinasi digunakan untuk menunjukkan kontribusi atau sumbangan variabel bebas (kualitas pelayanan dan fasilitas) terhadap variabel kepuasan siswa. Berikut tabel hasil uji determinasi.

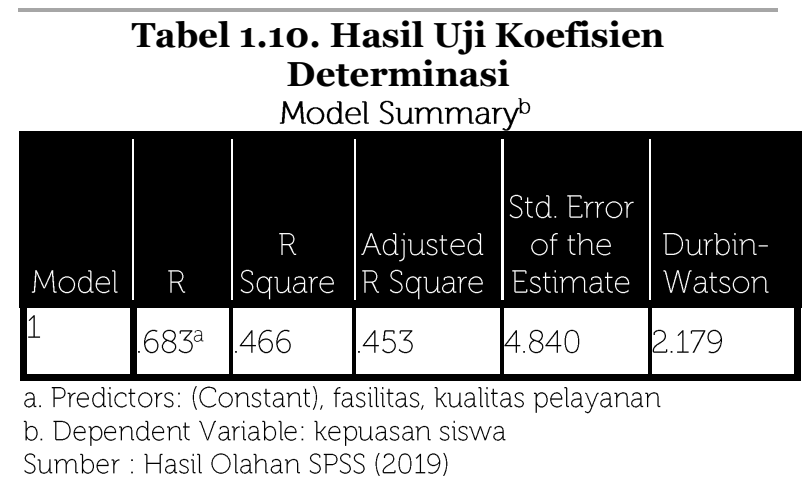

Berdasarkan tabel di atas, diperoleh nilai $R$ Square yaitu 0.466 yang artinya bahwa kualitas pelayanan dan fasilitas memberikan 
kontribusi terhadap kepuasan siswa sebesar 46.6\% sedangkan sisanya $53.41 \%$ diterangkan oleh variabel lainnya.

\section{Uji t (Parsial)}

Uji t digunakan untuk mengetahui ada atau tidaknya pengaruh parsial antara kualitas pelayanan dan fasilitas terhadap kepuasan siswa.

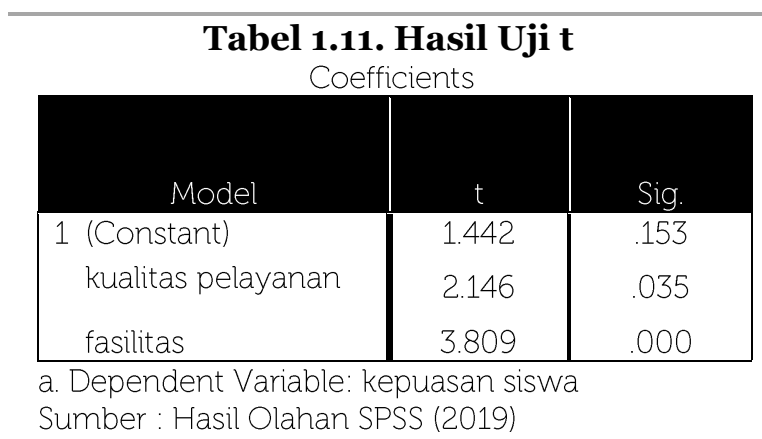

Berdasarkan hasil uji t hitung yang di dapat maka dapat diketahui bahwa:

1. Hasil uji t pengaruh kualitas pelayanan terhadap kepuasan diperoleh nilai $t$ hitung (2.146) > t tabel (1.988) dengan signifikan $0.035<0.1$ maka $\mathrm{H}_{\mathrm{O}}$ ditolak dan $\mathrm{H}_{\mathrm{a}}$ diterima menandakan bahwa kualitas pelayanan $\left(\mathrm{X}_{1}\right)$ mempunyai pengaruh yang positif dan signifikan terhadap kepuasan siswa(Y).

2. Hasil uji $t$ pengaruh fasilitas terhadap kepuasan diperoleh nilai t hitung (3.809) $>$ t tabel (1.988) dengan signifikan 0.000 < 0.1 maka $\mathrm{H}_{\mathrm{O}}$ ditolak dan $\mathrm{H}_{\mathrm{a}}$ diterima menandakan bahwa fasilitas $\left(\mathrm{X}_{2}\right)$ mempunyai pengaruh yang positif dan signifikan terhadap kepuasan siswa(Y).

\section{Pembahasan}

1. Kualitas pelayanan pada SMK Yadika 5 masih katagori baik dengan skor 3.89 ada pada interval 3.41-4.20 serta terdapat pengaruh positif antara kualitas pelayanan $\left(\mathrm{X}_{1}\right)$ terhadap kepuasan siswa (Y). Hal ini dapat dilihat dari koefisien regresi linier sederhana $\mathrm{Y}=7.553+0.75 \mathrm{X}_{1}$ nilai koefisien determinasi sebesar $37.2 \%$ artinya kualitas pelayanan memiliki pengaruh sebesar 37.2\% sedangkan sisanya sebesar $62.8 \%$ dari pengujian $t$ hitung $2.146>\mathrm{t}$ tabel 1.988 dan signifikansi 0,035<0,05.

2. Fasilitas masih katagori baik dengan skor 3.86 ada pada interval 3.41-4.20 serta terdapat pengaruh positif antara fasilitas $\left(\mathrm{X}_{2}\right)$ terhadap kepuasan siswa $(\mathrm{Y})$. Hal ini dapat dilihat dari koefisien regresi linier sederhana $\mathrm{Y}=10.383+0.68 \mathrm{X}_{2}$ nilai koefisien determinasi sebesar $43.6 \%$ artinya fasilitas memiliki pengaruh sebesar $43.6 \%$ sedangkan sisanya sebesar $56.4 \%$ sedangkan sisanya sebesar dari pengujian thitung 3.809 $>\mathrm{t}$ tabel 1.988 dan signifikansi 0,000 <0,05.

3. Kepuasan siswa masih katagori baik dengan skor 3.78 ada pada interval 3.414.20 serta terdapat pengaruh positif antara kualitas pelayanan $\left(\mathrm{X}_{1}\right)$ dan fasilitas $\left(\mathrm{X}_{2}\right)$ terhadap kepuasan siswa (Y). Hal ini dapat dilihat dari koefisien regresi linier berganda $\mathrm{Y}=5.677+$ 
$0.32 \mathrm{X}_{1}+0.48 \mathrm{X}_{2}$ nilai koefisien determinasi sebesar 46.6\%' artinya kualitas pelayanan dan fasilitas memiliki pengaruh sebesar $46.6 \%$ sedangkan sisanya $57.8 \%$ sebesar dari pengujian $\mathrm{F}$ hitung 34.557 > F tabel 2.36. serta faktor lain yang tidak diteliti.

\section{SIMPULAN}

\section{Kesimpulan}

1. Secara parsial kualitas pelayanan berpengaruh signifikan terhadap kepuasan siswa di SMK Yadika 5 dengan hasil uji $t$ parsial nilai $t_{\text {hitung }} 2.146>t_{\text {tabel }}$ 1.988 dan dan signifikansi 0,035<0,05.

2. Secara parsial fasilitas sekolah berpengaruh signifikan terhadap kepuasan siswa di SMK Yadika 5 dengan hasil uji t parsial nilai $t_{\text {hitung }} 3.809>t_{\text {tabel }} 1.988$ dan dan signifikansi $0,000<0,05$.

3. Secara simultan kualitas pelayanan dan fasilitas berpengaruh signifikan terhadap kepuasan siswa di SMK Yadika 5 dengan nilai uji $F_{\text {hitung 34.557 }}>\mathrm{F}_{\text {tabel }}$ 2.36. Hal ini dapat dilihat dari koefisien regresi linier berganda $\mathrm{Y}=5.677+0.32 \mathrm{X}_{1}+0.48 \mathrm{X}_{2}$ dan konstribusi pengaruh yang diberikan sebesar $46.6 \%$.

\section{Saran}

1. Kualitas pelayanan dan fasilitas yang diberikan yang tergolong baik, hendaknya tetap dapat dipertahankan dan ditingkat- kan oleh sekolah, sehingga akan meningkatkan kepuasan siswa.

2. Perlu adanya penelitian lanjutan yang dapat mengungkapkan faktor-faktor lainnya yang berpengaruh terhadap kepuasan siswa.

\section{DAFTAR PUSTAKA}

Ghozali,Imam. 2013. Aplikasi Multivariate dengan Program SPSS. Edisi Ketujuh.Badan penerbit. Universitas Diponogoro:Semarang

Http://Repository.Unpas.Ac.Id/15856/4/S KRIPSI\%2OBAB\%202.Pdf Diakses Tanggal 20 April 2019 Pukul 9.13. Http://Www.Organisasi.Org/1970/o1/Arti-

Definisi-Pengertian-Pemasaran-

Fungsi-Pemasaran-Marketing-Ilmu-

Manajemen-Pemasaran.Html. Diakses

Tanggal 20 April 2019 Pukul 9.16.

Http:/Www.Repository.Unpas.Ac.Id/

13059/4/BAB/202.Pdf, Diakses

Tanggal 20 April 2019 Pukul 9.13.

Philips Kotler dan Gery Amstrong .2012.

Manajemen Pemasaran, Edisi Ketigabelas jilid 1 Jakarta Erlangga.

Philips Kotler.2012. Manajemen Pemasaran, Edisi Ketigabelas jilid 1

Santoso, Singgih 2011. Sructural Equation Modeling (SEM) Konsep dan Aplikasi dengan Amos18. PT.Elex Media Komputido. Kompas Gramedia: Jakarta 
Santoso, Slamet. 2011, "Dinamika kelompok”. Penerbit bumi aksara, Jakarta.

Sugiyono, 2014. "Metode Penelitian Kuantitatif, Kualitatif dan R \& D" Penerbit CV.Alphabeta, Bandung.

Widyatama, .2014. Pengertian Hipotesis .

Widyatama, 2012. Prinsip-Prinsip pemasaran.

Widyatama, 2013. Indikator pemasaran menurut para ahli Tahun 2012 